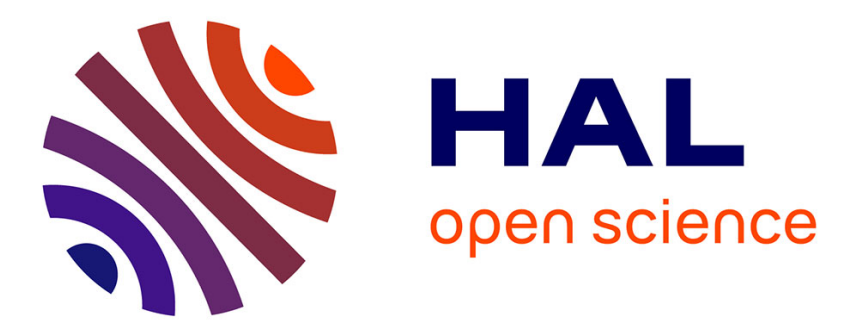

\title{
HCV genotype distribution in Flanders and Brussels (Belgium): unravelling the spread of an uncommon HCV genotype 5a cluster
}

J. Verbeeck, L. Kwanten, F. d'Heygere, A. Beguin, S. Michiels, I. Desombere, G. Leroux-Roels, P. Lemey, F. Nevens, M. Ranst

\section{To cite this version:}

J. Verbeeck, L. Kwanten, F. d'Heygere, A. Beguin, S. Michiels, et al.. HCV genotype distribution in Flanders and Brussels (Belgium): unravelling the spread of an uncommon HCV genotype 5a cluster. European Journal of Clinical Microbiology and Infectious Diseases, 2010, 29 (11), pp.1427-1434. 10.1007/s10096-010-1021-0 . hal-00621302

\section{HAL Id: hal-00621302 https://hal.science/hal-00621302}

Submitted on 10 Sep 2011

HAL is a multi-disciplinary open access archive for the deposit and dissemination of scientific research documents, whether they are published or not. The documents may come from teaching and research institutions in France or abroad, or from public or private research centers.
L'archive ouverte pluridisciplinaire HAL, est destinée au dépôt et à la diffusion de documents scientifiques de niveau recherche, publiés ou non, émanant des établissements d'enseignement et de recherche français ou étrangers, des laboratoires publics ou privés. 


\section{HCV genotype distribution in Flanders and Brussels (Belgium):}

2 Unravelling the spread of an uncommon HCV genotype 5a cluster

3

4

5

6

7

JANNiCK Verbeeck ${ }^{1}$, LeEn KWANTEN ${ }^{1}$, FranÇOIS D'Heygere ${ }^{2}$, Arne Beguin ${ }^{1}$, StiJn

Michiels ${ }^{1}$, Isabelle Desombere; ${ }^{3}$, Geert Leroux-Roels ${ }^{3}$, PhilipPe Lemey ${ }^{1,4}$, FREDERIK NEVENS ${ }^{5}$, AND MARC VAN RANST ${ }^{1 *}$

${ }^{1}$ Laboratory of Clinical Virology, Rega Institute for Medical Research, University of Leuven, Leuven, Belgium; ${ }^{2}$ Department of Gastroenterology, C.A.Z. Groeninge Kortrijk, Belgium;

${ }^{3}$ Center for Vaccinology, Ghent University and Hospital, Ghent, Belgium; ${ }^{4}$ Department of Zoology, University of Oxford, Oxford, United Kingdom; ${ }^{5}$ Division of Hepatology, University Hospital Gasthuisberg, Leuven, Belgium;

*Corresponding author. Mailing address: Laboratory of Clinical Virology, Rega Institute for Medical Research, University of Leuven, Minderbroedersstraat 10, BE-3000 Leuven, Belgium. Phone: +32-16-347908. Fax:+32-16-347900. Email: vanranstmarc@gmail.com

Word count abstract: 194

Word count article: 3505 
ABSTRACT

2 Purpose:

3 In order to study the hepatitis C virus (HCV) epidemiology in Flanders, Belgium, the

4 HCV genotype of 2301 patients diagnosed with HCV between 2001 and 2009 was

5 determined.

6 Methods:

7 HCV genotyping was conducted using the VERSANT LiPA 1.0 or VERSANT LiPA 2.0

8 assay. To explore the transmission history of a remarkable cluster of the rarely found

9 HCV genotype 5a, face-to-face interviews based on detailed questionnaires and 10 maximum likelihood phylogenetic analysis were performed.

11 Results:

12 HCV genotype 1 was the most prevalent genotype in all provinces, followed by $\mathrm{HCV}$ 13 genotype 3 in East-Flanders, Antwerp, Flemish-Brabant and Limburg. In Brussels, 14 HCV genotype 4 was the second most prevalent genotype. This observation is due to the 15 immigration of patients from the Middle East and Africa. Remarkably, a cluster of 16 HCV genotype 5a was found in West-Flanders, where it represents the second most 17 prevalent genotype accounting for $26.2 \%$ of $\mathrm{HCV}$ infections. We could not identify one 18 major transmission source explaining the whole HCV genotype 5a epidemic. Instead, 19 several smaller possible transmission chains were identified and confirmed 20 phylogenetically.

21 Conclusion:

22 Overall, the HCV genotype 5a epidemic in West-Flanders seems to be mainly associated 23 with blood transfusion and unsafe medical practices. 
1 Keywords: Belgium, epidemiology, HCV genotype 5a, HCV genotype distribution, hepatitis 1

2 2 2 C virus, phylogeny

4

53

6

7

8

9

10

11

12

13

14

15

16

17

18

19

20

21

22

23

24

25

26

27

28

29

30

31

32

33

34

35

36

37

38

39

40

41

42

43

44

45

46

47

48

49

50

51

52

53

54

55

56

57

58

59

60

61

62

63 
2 The hepatitis $\mathrm{C}$ virus (HCV) is a leading cause of chronic liver disease and confronts many

3 regions of the world with a severe disease burden. Worldwide, more than 170 million people

4 are infected with this virus [1]. Since its discovery in 1989, there is a growing interest in

5 different aspects of HCV research, including HCV epidemiology, evolution, host interactions

6 and antiviral defence mechanisms. Despite considerable research efforts, several aspects are

$7 \quad$ still poorly understood.

8 Phylogenetic analyses have revealed that HCV can be classified in 6 different genotypes and

9 multiple subtypes [2]. These six genotypes have different geographical distributions [3]. HCV

10 genotypes 1a, 1b and 3a are highly prevalent "epidemic" strains that are found globally. These

11 strains spread swiftly around the world during the twentieth century, most likely through 12 infected blood, blood products and injecting drug use, and have relatively low levels of 13 genetic variation. In contrast, other $\mathrm{HCV}$ strains are highly divergent but are found in 14 restricted geographic areas. These "endemic" strains reflect long-term transmission at low 15 levels in particular regions. Genotypes 1,2 and 4 appear to be endemic to regions of West and 16 Central Africa and the Middle East, whereas divergent endemic strains of genotypes 3 and 6 17 strains are found in South-East Asia [4]. HCV genotype 5a infections are mainly found in the 18 northern part of South Africa, where $40 \%$ of the HCV patients carry this genotype [5]. In 19 other regions of the world, HCV genotype 5a infections are scarce, and therefore, little is 20 known about the geographical distribution, evolution and treatment response of this 21 uncommon genotype.

22 In Belgium, $\mathrm{HCV}$ prevalence has been estimated at about $0.8 \%$, representing about 80.000 23 patients [6, 7]. A study of the epidemiological profile of HCV patients in Belgium conducted 24 between 1992 and 2002 showed that HCV genotype 1 is the most prevalent genotype, 25 followed by $\mathrm{HCV}$ genotype 3. HCV genotype 2 and HCV genotype 4 are roughly equally 
1 distributed, and HCV genotypes 5 and 6 are only encountered sporadically [8]. In 2006

2 however, a remarkable cluster of at least $100 \mathrm{HCV}$ genotype $5 \mathrm{a}$ infected patients was

3 identified in the West-Flanders province of Belgium [9].

4 In this paper, we describe the general epidemiological profile of HCV genotypes in Flanders,

5 Belgium for the period between 2001 and 2009. Next, we focus on the uncommon HCV

6 genotype 5a cluster in West-Flanders. In order to find out how HCV genotype 5a was

7 introduced in the population and to study its local spread, we conducted face-to-face

8 interviews with the infected patients using a detailed questionnaire to learn more about the

9 medical history and the HCV infection of each individual patient. We performed phylogenetic

10 analyses to confirm the links between the patients that were found during thorough

11 investigation of the questionnaires. 
MATERIALS AND METHODS

\section{Study population}

3 Between January 2001 and August 2009, blood samples of 2301 new patients with chronic

4 hepatitis $\mathrm{C}$ were received for HCV genotyping at the University Hospital of Leuven. Only

5 HCV carriers presenting for the first time were included in this study. The study population

6 consists of blood samples from patients attending the medical consultation at the hospital and

7 blood samples from outpatients from other hospitals in Flanders that do not have their own

8 HCV genotyping facilities. Patients with anti-HCV antibodies who are HCV RNA negative

9 are not included. The selected study population is a representative sample of the total HCV

10 population in Flanders since patients from all provinces are included.

11 Genotyping was performed using the INNO LiPA 1.0 or the INNO LiPA 2.0 (developed by 12 Innogenetics Inc., Ghent, Belgium and distributed by Siemens Healthcare Diagnostics, IL, 13 USA) according to the manufacturer's instructions. Demographic and geographic information 14 (age, gender, city of residence) were collected for all patients.

15 Patients infected with HCV genotype 5a were invited to participate in our study. In total, 67 16 patients were willing to participate. Informed consent was obtained from all patients. Face-to17 face interviews based on a detailed questionnaire were conducted for all 67 patients in order 18 to explore possible transmission routes. The questionnaire investigated HCV diagnosis, HCV 19 treatment outcome, HCV family history, hospitalisation history, general medical care, blood 20 transfusion history, contact with blood products, blood donations, military history, tattooing, 21 piercing, acupuncture, IDU, visits to general doctors, visits to dentists, travelling to foreign 22 countries, and possible links with South Africa. For the female patients, additional questions 23 concerning pregnancy and childbirth were included. The study was approved by the ethical 24 committee of the University Hospital Leuven. 


\section{Phylogenetic analysis}

2 In order to reconstruct the phylogenetic relationships between the HCV genotype 5a patients,

398 serum samples were collected from 61 different patients. Viral RNA was isolated from 140

$4 \quad \mu 1$ serum using the QIAamp Viral RNA Mini kit (Qiagen Benelux B.V., Venlo, the

5 Netherlands) according to the manufacturer's instructions, and eluted in $60 \mu 1$ elution buffer.

6 One-step reverse transcription PCRs were carried out using the OneStep RT-PCR kit (Qiagen)

7 to amplify a 584 bp fragment from the highly variable E1-E2 region (genome location: nt 554

8 to nt 1138 according to the numbering of the $\mathrm{H} 77$ strain) and a $573 \mathrm{bp}$ fragment from the

9 more conserved NS3-NS4 region (genome location: nt 5058 to nt 5631 according to the

10 numbering of the $\mathrm{H} 77$ strain) as described previously [9]. Purified DNA fragments were

11 directly sequenced on both strands using the ABI Prism BigDye Terminator Cycle

12 Sequencing Reaction Kit (Applied Biosystems).

13 Multiple nucleotide sequence alignments were created for the E1-E2 region, NS3-NS4 region,

14 and the concatenated E1-NS4 region using the Clustal X program version 1.83 [10].

15 Alignments were adjusted by hand. For the E1-E2 region, the hypervariable region was

16 excluded from the analysis, since it is impossible to unambiguously align this region.

17 Molecular phylogenies were estimated for each alignment using a maximum-likelihood (ML)

18 approach implemented in PAUP* v4.0b [11]. Model selection for each sequence alignment 19 was performed with the Modeltest 3.7 software [12] under the Aikake Information Criterion. 20 For the E1-E2 region and the concatenated region, the general time reversible model with 21 gamma distributed rate heterogeneity among sites and invariable sites $(\mathrm{GTR}+\mathrm{I}+\mathrm{G})$ was 22 selected. For the NS3-NS4 region, the transversional model with gamma distributed rate 23 heterogeneity among sites and invariable sites $(\mathrm{TVM}+\mathrm{I}+\mathrm{G})$ had the smallest AIC score. 24 Substitution model parameters were estimated on a initial neighbor-joining tree and were 25 fixed throughout heuristic search optimization during which the NNI branch-swapping 
1 algorithm was used. Bootstrap analysis was performed using 500 replicates to assess the 1 22 statistical robustness of the estimated phylogenies. 
RESULTS

\section{General HCV genotype distribution in Flanders, Belgium}

3 In this study, the HCV genotype of $2301 \mathrm{HCV}$ positive patients was determined. HCV

4 genotype 1 was the most prevalent genotype and was found in $1401(60.9 \%)$ of patients. HCV

5 genotype 3 was the second most prevalent genotype with 466 (20.3\%) infected patients,

6 followed by HCV genotype 4 (184 patients, 8.0\%), HCV genotype 2 (145 patients, 6.3\%) and

7 HCV genotype 5 (104 patients, 4.5\%). Only one patient was infected with HCV genotype 6.

8 No mixed infections with different genotypes were detected. HCV subtype information was

9 obtained for $80.4 \%$ of samples $(11.2 \% 1 \mathrm{a}, 42.6 \% 1 \mathrm{~b}, 0.7 \% 1 \mathrm{a} / 1 \mathrm{~b}, 3.6 \% 2 \mathrm{a} / 2 \mathrm{c}, 1.0 \% 2 \mathrm{~b}$,

$10 \quad 18.1 \% 3 \mathrm{a}, 0.1 \% 3 \mathrm{~b}, 0.3 \% 4 \mathrm{a} / 4 \mathrm{c} / 4 \mathrm{~d}, 2.4 \% 4 \mathrm{c} / 4 \mathrm{~d}, 0.2 \%$ ff and $0.2 \% 4 \mathrm{~h})$.

11 In total, 1392 (60.5\%) patients were male, and 909 (39.5\%) were female. For HCV genotypes

121 and 3, significantly more men were infected than women (Pearson Chi-Square tests, $13 \mathrm{P}<0.001)$. For the other $\mathrm{HCV}$ genotypes, no significant differences according to gender could 14 be found. The mean age \pm SD of the total study population was $51.5 \pm 15.6$ years (range: 5 15 94). Patients infected with HCV genotype 3 were significantly younger than patients infected 16 with one of the other genotypes $(42.4 \pm 10.3$ years; range: 5-84; Mann-Whitney test, $17 \mathrm{P}<0.001)$.

\section{Description of HCV genotype 5a cluster in West-Flanders, Belgium}

20 Figure 1 displays the HCV genotype distribution for the northern part of Belgium (Flanders 21 and Brussels). For the southern part of Belgium only 37 samples were collected in the 22 different provinces. Since this number is too low to represent the general genotype 23 distribution in the southern part of Belgium, these data were deleted from the dataset for 24 further analyses. 
1 In each province, HCV genotype 1 is the most prevalent. In Antwerp, Limburg, East-Flanders

2 and Flemish-Brabant, $\mathrm{HCV}$ genotype 1 is followed by $\mathrm{HCV}$ genotypes 3, 4, 2 and 5a

3 respectively. In Brussels, $\mathrm{HCV}$ genotype 4 is more prevalent than $\mathrm{HCV}$ genotype 3.

4 Remarkably, HCV genotype 5a is a minor genotype in all provinces, except for West-

5 Flanders, were it is the second most prevalent genotype. In this province, more than a quarter

6 of the patients $(26.2 \%)$ is infected with the uncommon HCV genotype 5a. A Pearson Chi-

7 Square test indicated that the number of HCV genotype 5a patients is significantly higher

8 compared to the number of HCV genotype 5a patients in other provinces $(\mathrm{P}<0.001)$. The

9 HCV genotype 5a patients are significantly older (mean age $62 \pm 14.7$; range: 13 - 88; Mann-

10 Whitney test: $\mathrm{P}<0.001)$.

11 The data on the treatment response of the HCV genotype 5a patients are not based on the 12 official medical records, but on the information given by the patients during the interview. 13 Therefore, we do not have the exact information on the dosage for each patient. In total, 49 14 patients received antiviral therapy. Of these, 59.2\% (29/49) showed sustained virological 15 response (SVR) after completion of therapy, $14.3 \%$ (7/49) were non-responders, and $26.5 \%$ 16 (13/49) relapsed after therapy.

17

18

\section{Epidemiological investigation of the HCV genotype 5a cluster in Flanders}

In total, 104 patients were infected with HCV genotype 5a. Of these, 67 patients were willing to be interviewed at their home using a standardized questionnaire to identify potential risk factors. All 67 patients were born and are living in Belgium. Forty-four patients $(65.5 \%)$ are living in West-Flanders, 4 (6.0\%) in East-Flanders, 5 (7.5\%) in Flemish-Brabant, 6 (9.0\%) in Antwerp, 6 (9.0\%) in Limburg, and $2(3.0 \%)$ in Brussels.

Among the HCV genotype 5a patients, $49(73.1 \%)$ received blood transfusion and $24(35.8 \%)$ patients were blood donors before they were diagnosed with HCV. The questionnaire 
1 contained several questions that addressed the possibility of transmission via needles or

2 syringes. None of the patients reported a history of IDU. Thirteen patients underwent 3 acupuncture treatment, most of them at the practice of the family doctor. Two patients have a 4 tattoo, and 22 patients have one or more piercings. Seventeen patients received multiple 5 injections from multi-dose vials, mainly for pain relief. Two patients reported that they

6 received several injections during their military service, and that hygienic procedures were not 7 followed correctly. Vertical transmission does not seem to occur often, only two "mother8 child" couples were identified. The same holds for horizontal or familial transmission. We 9 identified only one "husband-wife" couple, one "father-son" couple and two sibling couples. 10 The patients were asked to give an overview of the family doctors and dentists that they 11 visited in the past. The names of three different family doctors appeared on top of the list. 12 These family doctors were mainly medically active between 1960 and 1980. Two of them are 13 also infected with HCV genotype 5a, and performed several deliveries. Patient-to-doctor or 14 doctor-to-patient transmission might have occurred since hygienic procedures were less strict 15 prior to the identification of $\mathrm{HCV}$ in 1989. No obvious links between HCV infection and 16 dentistry history were identified. Patients were also requested to provide us with an overview 17 of the surgical procedures they underwent and details on when and where these were 18 performed. Surgeries were executed in several hospitals, at different wards, and in a period

20 transmission and surgical history.

21 Since HCV genotype 5a is most frequently found in South Africa, we asked the patients if 22 they had ever visited that country and whether they had any direct contact with blood or blood 23 products during their stay in South Africa. Eight patients visited South Africa but none of 24 them had contact with blood products, which excludes the possibility that one of the patients 25 was infected in South Africa through blood products or surgery. Five patients had travelled to 
1 Congo. Two of them were active in a medical setting and performed surgical procedures

2 during their stay. Two other patients were there on holiday and reported no contact with blood

3 products. One patient was active in a military setting in Congo, and had a knee surgery during

4 his stay between 1959 and 1961.

\section{Phylogenetic reconstruction}

7 Serum samples from $61 \mathrm{HCV}$ genotype 5a infected patients were collected for phylogenetic 8 analysis. Thirty-one of these patients completed the questionnaire, enabling us to investigate

9 possible transmission routes in detail for this subset of patients. Figure 2 shows the

11 for clarity purpose. Each patient is identified by a unique identification number. Numbers in 12 bold represent patients of whom both a questionnaire and a serum sample were available. In 13 general, the phylogenetic signal of the dataset is rather low, since the main branches of the 14 tree are not supported by high bootstrap values. However, some smaller clusters with higher bootstrap values can be recognized. Remarkably, for most of these clusters, possible common infection sources were identified during detailed inspection of the questionnaires. The strains indicated in green originate from patients that visited the same family doctor for several years. The doctor himself is also infected with HCV genotype 5a, but unfortunately, we were not able to collect a serum sample. This sub-cluster (indicated by the dashed rectangle) harbours some additional strains from patients that live in the same rural area. We do not have a questionnaire from these patients and therefore can not confirm whether these patients also visited this family doctor. The strains indicated in orange correspond to a "mother-son" couple where vertical transmission occurred. The two patients who received multiple injections during their military service at the same military base, cluster together with a bootstrap value of 99 (strains indicated in blue). Three patients that do not live in West- 
1 Flanders also cluster with a high bootstrap value. The corresponding strains are indicated in

2 red. They all received blood transfusion in the same year and in the same geographical region.

3 One of the patients was also a blood donor in this geographical region before he/she was

4 diagnosed with $\mathrm{HCV}$, and delivered multiple blood donations during almost 10 consecutive

5 years. The strains shown in yellow are also associated with blood transfusion procedures.

6 Two of the three patients (BE03048920 and BE04458951) were blood donors in the same

7 geographic region and in the same year as the third patient (BE02218930) received a blood 8 transfusion.

9 The small clusters that can be observed for the concatenated gene region, were also present in 10 the phylogenetic trees of the separate E1-E2 region and NS3-NS4 region (data available on 11 request). 
DISCUSSION

2 This study aimed at evaluating the HCV genotype distribution in Flanders and Brussels

3 (Belgium) and at investigating the mechanisms underlying the occurrence and spread of an

4 uncommon HCV genotype 5a cluster which was described in a previous study [9].

5 The global genotype distribution in our patient group indicates that HCV genotype 1 is

6 dominant, followed by HCV genotype 3, HCV genotype 4, HCV genotype 2, HCV genotype

75 and $\mathrm{HCV}$ genotype 6 . This distribution pattern largely corresponds to the results obtained

8 during a previous survey performed in drug users from Belgium in 2005 [13]. Since the study

9 population in this study was limited to drug users, the reported prevalence of HCV genotype 3

10 was higher than in our study. Compared to the results reported by Gérard and colleagues [8],

11 the proportion of HCV genotype 3 patients in Belgium seems to be growing over the last

12 decade. This phenomenon is also observed in other European countries [14-17] and is 13 probably due to the increase of injecting drug use (IDU) contamination, which has become 14 the most common way of new HCV transmission since blood screening became available in 151991 [18]. Patients infected with HCV genotype 3 were significantly younger than patients 16 infected with one of the other HCV genotypes in our dataset. This also fits in the IDU 17 scenario. Since HCV genotype 3 has recently been associated with accelerated fibrosis 18 progression [19], the growing share of this genotype may have important consequences for 19 the management of patients infected with this genotype.

20 In the Brussels capital region, HCV genotype 4 is the second most prevalent genotype. This 21 HCV genotype is most common in the Middle East and in Northern and Central Africa [20]. 22 Egypt has the highest HCV prevalence worldwide, and more than $90 \%$ of the patients are 23 infected with HCV genotype 4 [21]. Recent studies indicate that HCV genotype 4 prevalence 24 has increased in European countries due to the immigration of HCV genotype 4-infected 25 patients [22-27]. A study on the emergence of HCV genotype 4 in The Netherlands revealed 
1 three epidemiological profiles, one associated with immigration from the Middle East and

2 Africa, a second profile linked to injecting drug use, and a third one consisting of men who 3 have sex with men (MSM) that are co-infected with HIV [28]. Brussels is a geographical

4 region with a relatively high immigration rate, which could be a possible explanation for the 5 rise in HCV genotype 4 prevalence in this region. Moreover, HCV genotype 4 is increasing in 6 the IDU population in Belgium (personnel communication, Frederik Nevens).

7 Another remarkable finding is the fact that $\mathrm{HCV}$ genotype $5 \mathrm{a}$ is the second most prevalent 8 genotype in West-Flanders, whereas it is only found sporadically in other Flemish provinces.

9 In order to study the epidemiology of HCV genotype 5a in Flanders, a thorough investigation

11 For the patients infected with non-genotype 5a strains, epidemiological information is 12 lacking. Therefore, we are unable to discuss risk factors associated with transmission for these 13 HCV genotypes, and we can not compare the HCV genotype distribution in different risk 14 groups which is a drawback of our study. A survey in HCV patients using a simple 15 questionnaire during the consultations as suggested by De Maeght and colleagues [29] can 16 provide information on the risk factors and transmission profiles of $\mathrm{HCV}$ in Belgium.

17 The main transmission route for this HCV genotype seems to be blood transfusion, as $73.1 \%$ 18 of the HCV genotype 5a patients received one or more transfusions before they were diagnosed with HCV. Moreover, 24 patients (35.8\%) were blood donors before they were diagnosed with $\mathrm{HCV}$, and they may have unconsciously contributed to the spread of the HCV genotype 5a virus. In our previous study addressing the origin and spread of HCV genotype 5a, we hypothesized that transmission of HCV genotype 5a in Belgium was mainly associated with contaminated blood products, and that HCV has been circulating in Belgium since mid 1800 [9]. A study on the epidemiology of HCV genotype 5a in central France suggests that this uncommon genotype was transmitted by iatrogenic route before 1972 in this region, and 
1 later on via transfusion to the whole district [30]. In Syria, transmission via blood transfusion,

2 IDU and tattooing was identified in $30 \%$ of the HCV genotype 5a patients, while no obvious

3 transmission mechanism could explain the infection in the remaining portion of patients [31].

4 In southeast Spain, the origin of infection was unknown for $80 \%$ of the patients, $16 \%$

5 acquired infection by blood transfusion and $4 \%$ of patients were IDUs [32].

6 In contrast to HCV genotypes 1, 3 and 4 for which epidemiological data are well established,

7 the epidemic spread of HCV genotype 5a remains unknown. Since HCV genotype 5a is the 8 predominant genotype in South Africa [5], it may well be that this genotype originated in that

9 part of the world and was subsequently introduced in Belgium. However, our study reveals no

10 direct epidemiological links with South Africa. Although HCV genotype 5a is not commonly

11 found in Congo, we hypothesized in a previous study that this region could harbour the 12 original source of this genotype [9]. One general surgeon and one urologist were 13 professionally active in Congo, so it is possible that they had contact with HCV infected 14 patients during their stay.

15 Since HCV genotype 5a infections are rare, they theoretically represent an excellent marker to 16 follow the epidemiological spread. Tracing the predominant transmission routes mainly 17 depends on information obtained from the patients themselves, and is therefore subjected to 18 the obvious disadvantages of this kind of studies, such as recall bias. However the results of 19 our phylogenetic analysis confirm some findings of the face-to-face interviews. Based on the 20 combined results of both the epidemiological and phylogenetic study, small and localized 21 clusters of transmission have been identified. When, where and how HCV genotype 5a 22 originated and started spreading in the human population, still remains an unsolved issue. Our 23 results suggest that several independent transmission events have led to the local spread of 24 this genotype, and that transfusion and unsafe medical practices are the main transmission 25 routes for HCV genotype 5a in Flanders, Belgium. 
1

2 3 4 5 6 7 8 9 10

2 We would like to thank all HCV genotype 5a patients for their kind participation in our study.

3 PL was supported by a postdoctoral fellowship from the Fund for Scientific Research (FWO)

4 Flanders and FWO grant G.0513.06.

5

6 


\section{References}

[1] WHO (1999) Global surveillance and control of hepatitis C. Report of a WHO Consultation organized in collaboration with the Viral Hepatitis Prevention Board, Antwerp, Belgium. Journal of viral hepatitis 6 (1):35-47

[2] Simmonds P, Bukh J, Combet C, Deleage G, Enomoto N, Feinstone S, Halfon P, Inchauspe G, Kuiken C, Maertens G, Mizokami M, Murphy DG, Okamoto H, Pawlotsky JM, Penin F, Sablon E, Shin IT, Stuyver LJ, Thiel HJ, Viazov S, Weiner AJ, Widell A (2005) Consensus proposals for a unified system of nomenclature of hepatitis C virus genotypes. Hepatology 42 (4):962-973

[3] Cristina J (2005) Genetic diversity and evolution of hepatitis C virus in the Latin American region. J Clin Virol 34 Suppl 2:S1-7

[4] Pawlotsky JM (2003) Hepatitis C virus genetic variability: pathogenic and clinical implications. Clinics in liver disease 7 (1):45-66

14 [5] Chamberlain RW, Adams NJ, Taylor LA, Simmonds P, Elliott RM (1997) The 15 complete coding sequence of hepatitis $\mathrm{C}$ virus genotype $5 \mathrm{a}$, the predominant genotype in

South Africa. Biochemical and biophysical research communications 236 (1):44-49

[6] Beutels M, Van Damme P, Aelvoet W, Desmyter J, Dondeyne F, Goilav C, Mak R, Muylle L, Pierard D, Stroobant A, Van Loock F, Waumans P, Vranckx R (1997) Prevalence of hepatitis A, B and C in the Flemish population. European journal of epidemiology 13 (3):275-280

[7] Van Damme P, Thyssen A, Van Loock F (2002) Epidemiology of hepatitis C in Belgium: present and future. Acta Gastroenterol Belg 65 (2):78-79

[8] Gerard C, Delwaide J, Vaira D, Bastens B, Servais B, Wain E, Bataille C, Daenen G, Belaiche J (2005) Evolution over a 10 year period of the epidemiological profile of 1,726 newly diagnosed HCV patients in Belgium. Journal of medical virology 76 (4):503-510

[9] Verbeeck J, Maes P, Lemey P, Pybus OG, Wollants E, Song E, Nevens F, Fevery J, Delport W, Van der Merwe S, Van Ranst M (2006) Investigating the origin and spread of hepatitis C virus genotype 5a. Journal of virology 80 (9):4220-4226

[10] Higgins DG, Sharp PM (1988) CLUSTAL: a package for performing multiple sequence alignment on a microcomputer. Gene 73 (1):237-244

[11] Swofford DL (2002) PAUP*: Phylogenetic Analysis Using Parsimony (*and other methods), version 4. Sinauer Associates, Sunderland, MA, USA

[12] Posada D, Crandall KA (1998) MODELTEST: testing the model of DNA substitution. Bioinformatics 14 (9):817-818

[13] Mathei C, Wollants E, Verbeeck J, Van Ranst M, Robaeys G, Van Damme P, Buntinx F (2005) Molecular epidemiology of hepatitis C among drug users in Flanders, Belgium: association of genotype with clinical parameters and with sex- and drug-related risk behaviours. Eur J Clin Microbiol Infect Dis 24 (8):514-522

[14] Roman F, Hawotte K, Struck D, Ternes AM, Servais JY, Arendt V, Hoffman P, Hemmer R, Staub T, Seguin-Devaux C, Schmit JC (2008) Hepatitis C virus genotypes distribution and transmission risk factors in Luxembourg from 1991 to 2006. World J Gastroenterol 14 (8):1237-1243

[15] Chlabicz S, Flisiak R, Kowalczuk O, Grzeszczuk A, Pytel-Krolczuk B, Prokopowicz D, Chyczewski L (2008) Changing HCV genotypes distribution in Poland--relation to source and time of infection. J Clin Virol 42 (2):156-159

[16] Bourliere M, Barberin JM, Rotily M, Guagliardo V, Portal I, Lecomte L, Benali S, Boustiere C, Perrier H, Jullien M, Lambot G, Loyer R, LeBars O, Daniel R, Khiri H, Halfon P (2002) Epidemiological changes in hepatitis $C$ virus genotypes in France: evidence in intravenous drug users. Journal of viral hepatitis 9 (1):62-70 
1 [17] Christofidou M, Lambropoulou-Karatza C, Dimitracopoulos G, Spiliopoulou I (2000) Distribution of hepatitis $\mathbf{C}$ virus genotypes in viremic patients with beta-thalassemia. Eur $\mathbf{J}$ Clin Microbiol Infect Dis 19 (9):728-730 [18] Kleter B, Brouwer JT, Nevens F, van Doorn LJ, Elewaut A, Versieck J, Michielsen PP, Hautekeete ML, Chamuleau RA, Brenard R, Bourgeois N, Adler M, Quint WG, genotypes: epidemiological and clinical associations. Benelux Study Group on Treatment of Chronic Hepatitis C. Liver 18 (1):32-38

[19] Bochud PY, Cai T, Overbeck K, Bochud M, Dufour JF, Mullhaupt B, Borovicka J, Heim M, Moradpour D, Cerny A, Malinverni R, Francioli P, Negro F (2009) Genotype 3 is associated with accelerated fibrosis progression in chronic hepatitis C. Journal of hepatology 51 (4):655-666

[20] Smith DB, Pathirana S, Davidson F, Lawlor E, Power J, Yap PL, Simmonds P (1997) The origin of hepatitis $C$ virus genotypes. The Journal of general virology 78:321-328

[21] Ray SC, Arthur RR, Carella A, Bukh J, Thomas DL (2000) Genetic epidemiology of hepatitis C virus throughout egypt. The Journal of infectious diseases 182 (3):698-707

[22] Ansaldi F, Bruzzone B, Salmaso S, Rota MC, Durando P, Gasparini R, Icardi G (2005) Different seroprevalence and molecular epidemiology patterns of hepatitis $C$ virus infection in Italy. Journal of medical virology 76 (3):327-332

[23] Delwaide J, Reenaers C, Gerard C, Vaira D, Bastens B, Servais B, Bekhti A, Bataille C, Wain E, De Leeuw P, Daenen G, Mesureur T, Sente JM, Belaiche J (2006) HCV genotype 4 in Belgium: three distinct patterns among patients from European and African origin. Eur J Gastroenterol Hepatol 18 (7):707-712

[24] Payan C, Roudot-Thoraval F, Marcellin P, Bled N, Duverlie G, Fouchard-Hubert I, Trimoulet P, Couzigou P, Cointe D, Chaput C, Henquell C, Abergel A, Pawlotsky JM, Hezode C, Coude M, Blanchi A, Alain S, Loustaud-Ratti V, Chevallier P, Trepo C, Gerolami V, Portal I, Halfon P, Bourliere M, Bogard M, Plouvier E, Laffont C, Agius G, Silvain C, Brodard V, Thiefin G, Buffet-Janvresse C, Riachi G, Grattard F, Bourlet T, Stoll-Keller F, Doffoel M, Izopet J, Barange K, Martinot-Peignoux M, Branger M, Rosenberg A, Sogni P, Chaix ML, Pol S, Thibault V, Opolon P, Charrois A, Serfaty L, Fouqueray B, Grange JD, Lefrere JJ, Lunel-Fabiani F (2005) Changing of hepatitis C virus genotype patterns in France at the beginning of the third millenium: The GEMHEP GenoCII Study. Journal of viral hepatitis 12 (4):405-413

[25] Schroter M, Zollner B, Schafer P, Reimer A, Muller M, Laufs R, Feucht HH (2002) Epidemiological dynamics of hepatitis $\mathrm{C}$ virus among 747 German individuals: new subtypes on the advance. Journal of clinical microbiology 40 (5):1866-1868

[26] van Asten L, Verhaest I, Lamzira S, Hernandez-Aguado I, Zangerle R, Boufassa F, Rezza G, Broers B, Robertson JR, Brettle RP, McMenamin J, Prins M, Cochrane A, Simmonds P, Coutinho RA, Bruisten S (2004) Spread of hepatitis C virus among European injection drug users infected with HIV: a phylogenetic analysis. The Journal of infectious diseases 189 (2):292-302

[27] van de Laar TJ, Langendam MW, Bruisten SM, Welp EA, Verhaest I, van Ameijden EJ, Coutinho RA, Prins M (2005) Changes in risk behavior and dynamics of hepatitis C virus infections among young drug users in Amsterdam, the Netherlands. Journal of medical virology 77 (4):509-518

[28] de Bruijne J, Schinkel J, Prins M, Koekkoek SM, Aronson SJ, van Ballegooijen MW, Reesink HW, Molenkamp R, van de Laar TJ (2009) Emergence of hepatitis C virus genotype 4: phylogenetic analysis reveals three distinct epidemiological profiles. Journal of clinical microbiology 47 (12):3832-3838 
1 [29] De Maeght S, Henrion J, Bourgeois N, de Galocsy C, Langlet P, Michielsen P, Reynaert H, Robaeys G, Sprengers D, Orlent H, Adler M (2008) A pilot observational survey of hepatitis C in Belgium. Acta Gastroenterol Belg 71 (1):4-8

[30] Abergel A, Ughetto S, Dubost S, Bonny C, Aublet-Cuvelier B, Delarocque-Astagneau E, Bailly JL, Bommelaer G, Casanova S, Delteil J, Deny P, Laurichesse H, Odent-Malaure H, Roussel J, Peigue-Lafeuille H, Henquell C (2007) The epidemiology and virology of hepatitis $\mathrm{C}$ virus genotype 5 in central France. Alimentary pharmacology \& therapeutics 26 (10):14371446

[31] Antaki N, Haddad M, Kebbewar K, Abdelwahab J, Hamed O, Aaraj R, Alhaj N, 10 Haffar S, Assil M, Ftayeh M, Assaad F, Doghman D, Ali T, Nasserelddine M, Ali A, Antaki 11 F (2009) The unexpected discovery of a focus of hepatitis C virus genotype 5 in a Syrian 12 province. Epidemiol Infect 137 (1):79-84

13 [32] Jover R, Perez-Serra J, de Vera F, Alamo JM, Munoz C, Yago C, Martinez-Ramirez 14 R, Vidal JV (2001) Infection by genotype 5a of HCV in a district of southeast Spain. Am J 15 Gastroenterol 96 (10):3042-3043 
3 Fig 1 Geographic distribution of the HCV genotypes in Flanders and Brussels (Belgium). The

4 pie charts are scaled according to the number of samples analysed in each province.

6 Fig 2 Phylogenetic maximum likelihood tree for the concatenated gene region of $\mathrm{HCV}$

7 genotype 5a strains. Each strain is indicated by a unique patient number. Strain names printed

8 in bold correspond to patients from whom both a serum sample and a questionnaire were

9 available. Possible inter-patient transmission clusters are indicated by a colour code (see text

10 for further details). Numbers at the nodes represent bootstrap values. Only values of $>50$ are 11 shown. 
Figure 1

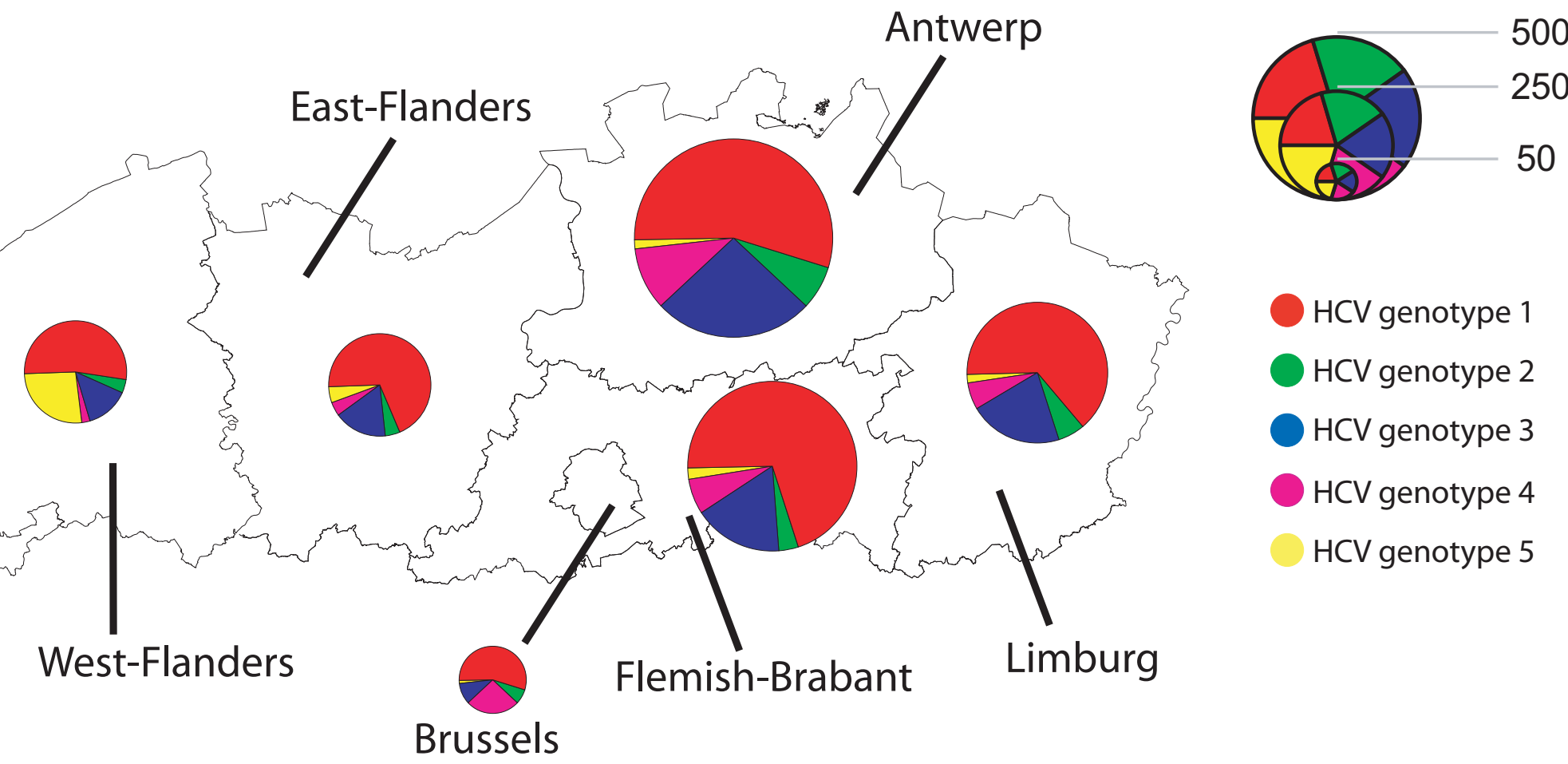


Figure 2

\section{Figure 2}

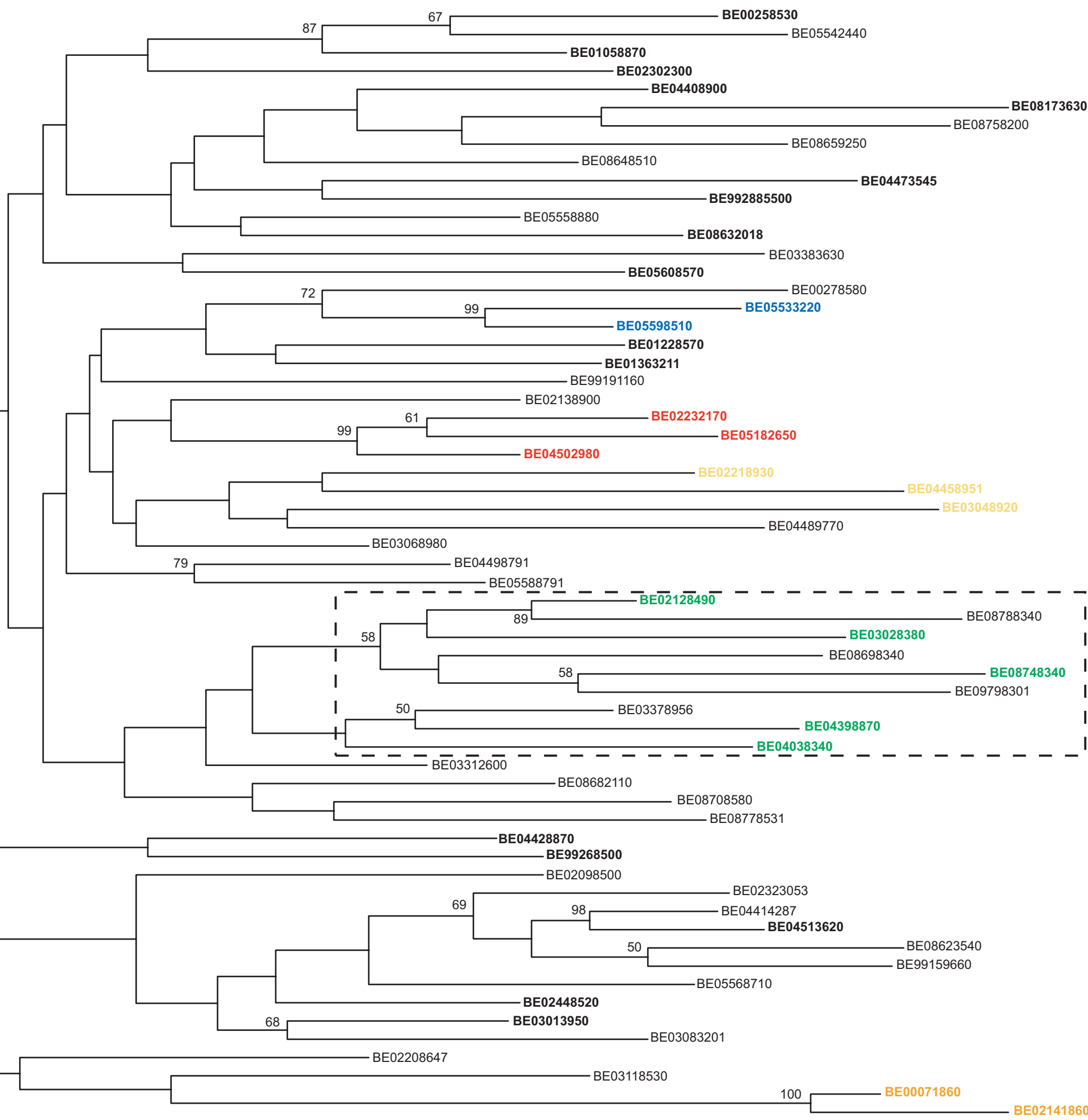

